\title{
Is The Higher Debt Level Profitable for State-Owned Enterprises?
}

\author{
Submitted 25/12/20, $1^{\text {st }}$ revision $28 / 01 / 21,2^{\text {nd }}$ revision 19/02/21, accepted 20/03/21
}

\section{Bambang Sutopo ${ }^{1}$, Arum Kusumaningdyah Adiati $^{2}$, Purnama Siddi ${ }^{3}$}

\begin{abstract}
:
Purpose: The need for more significant debt financing to achieve higher profitability of State-Owned Enterprises (SOEs) is an issue that has recently attracted public attention in Indonesia. This study examines how SOE debt financing is associated with profitability when the debt level is relatively low and relatively high.

Design/Methodology/Approach: The sample includes 514 SOE observations in the 20142018 period. Regression models are used to test the research hypotheses.

Findings: The regression results show a positive association between debt financing and profitability when debt levels are low. On the other hand, the results show that the relationship is negative when debt levels are high. These results are consistent after controlling for the size, type, and industrial sector of the SOEs and observation year.

Practical Implications: These findings suggest the need for controlling SOE debt financing to achieve SOE objectives in generating profits in Indonesia.

Originality/value: By splitting the sample into low and high debt levels, this study presents findings that can show when debt financing can increase profitability and reduce SOEs' profitability.
\end{abstract}

Keywords: Debt financing, debt levels, profitability, state-owned enterprises (SOEs), Indonesia.

JEL classification: C21, L32, M10, M48.

Paper Type: Research study.

Acknowledgment: We want to acknowledge the encouragement for research and publication of Sebelas Maret University's results.

\footnotetext{
${ }^{1}$ Prof. Accounting Department, Faculty of Economics and Business, Universitas Sebelas Maret, Indonesia, bbsutopo@yahoo.com

${ }^{2}$ Accounting Department and Chair of the Career Development Center, Faculty of Economics and Business, Universitas Sebelas Maret, Indonesia, adiati_rk@yahoo.com ${ }^{3}$ Accounting Department, Faculty of Economics, Universitas Islam Batik Surakarta, Indonesia, purnamasiddi.1004@gmail.com
} 


\section{Introduction}

As a business entity, a State-Owned Enterprise (SOE) has the goal of pursuing profits. In Indonesia, this objective is stated in Law no. 19 of 2003 (UU.19, 2003). To achieve high profits, SOEs have flexibility in determining their financial policies, including determining their capital structure.

Debt financing and its relation to SOES profits have attracted the attention of the public lately. Some opinions support debt financing to generate profits for SOEs, and conversely, some opinions disagree with that. There are interesting cases of SOE debt and profitability in 2018. PT Pelayaran Nasional Indonesia (Persero), abbreviated as PELNI, with debt financing (the ratio of total liabilities to total assets, TLTA) of 0.10 results in profitability (the ratio of profit after tax to total assets, EATTA) of 0.03. Meanwhile, PT Garam (Persero), with a TLTA of 0.17 (which is more significant than TLTA PELNI), can reach an EATTA of 0.13 (which is also higher than EATTA PELNI). However, PT Pupuk Indonesia (Persero) with a TLTA of 0.52 (which is more significant than TLTA PELNI and TLTA GARAM) obtained an EATTA of 0.03 (lower than EATTA PELNI or EATTA PT GARAM).

Previous studies have provided inconsistent results. For example, debt has a negative association with profitability (Collins, Clement, and Funke, 2013; Habib and Khan, 2016; Lin and Rowe, 2006; Nguyen, Nguyen, Tran, and Nghiem, 2019; Obert and Olawale, 2010; Olufunso, Herbst, and Roberts-Lombard, 2010; Raisa and Cristian, 2015; Shah and Ilyas, 2014; Wahyudi, Mujibatun, and Riduwan, 2019; Waluyo, 2018). Conversely, there is a positive association between debt and profitability (Harelimana, 2017; Holz, 2002; Kartikasari and Merianti, 2016). Meanwhile, debt is not associated with profitability (Amanda, 2019; Hadiah, 2016; Harisa, Adam, and Meutia, 2019; Kebewar and Shah, 2012).

From these studies, a research gap was identified that there is no explanation as to why debt's effect on profitability can be positive or negative in one study. This motivated this study to fill the research gap. This study is conducted by testing the debt-profitability association for the full sample, and then it is continued by testing the debt-profitability association for the low and high debt level subsamples. These methods are designed to find practical explanations of the impact of debt on profitability that can be positive or negative.

\section{State-Owned Enterprises in Indonesia}

An SOE can be a "Perusahaan Umum," from now on referred to as "Perum" or a "Perusahaan Perseroan," from now on referred to as "Persero". The main difference between Perum and Persero is in the capital owned by the state. Perum capital is not divided into shares and is entirely owned by the state. Persero's capital is divided into shares, and the state owns at least 51 percent. The similarity is that both have the goal of achieving profit. Persero can be a "Persero Terbuka" that can offer its 
shares to the public, generally thru the capital market (UU.19, 2003).

The number of Perum in Indonesia from 2014-2018 has not changed, as many as 14 SOEs. The number of Persero was reduced from 119 (2014) to 118 SOES (2015) due to a merger. There were 119 Persero's in 2014, and this number decreased to 118 in 2015 due to a merger. This number drops again to 115 (2017) due to the transfer of shares of several SOEs to a holding SOE.

Every year SOEs contribute to state revenue. For example, in the 2018 state budget, state revenue from SOEs, which is the income from Separated State Assets, is IDR 44,695,387,920,000 (UU.15, 2017). This state revenue can be fulfilled by SOEs that generate profits. However, as many as seven SOEs still recorded losses. Ironically, the seven SOEs have received a capital injection from the government thru State Capital Participation (Penyertaan Modal Negara, PMN). During the 2015-2019 period, the Ministry of Finance allocated PMN to several state-owned companies, including IDR 65.6 trillion in 2015 and IDR 51.9 trillion in 2016. Then in 2017, it dropped dramatically to only Rp. 9.2 trillion and in 2018 Rp. 3.6 trillion. Even so, the capital injection from the state budget in recent years has not guaranteed the company's financial performance to improve (Idris, 2019).

\section{Debt Financing and Profitability}

Sources of funds from debt can contribute to increased profitability, but on the contrary, it can have an impact on reducing profitability. Higher debt will be beneficial for a company if it is followed by its ability to manage these funds to produce higher profitability. Previous studies have reported inconsistent findings. For example, debt positively impacts profitability (Harelimana, 2017; Kartikasari and Merianti, 2016). In contrast, debt negatively associates profitability (Habib and Khan, 2016; Nguyen and Crase, 2011; Raisa and Cristian, 2015; Wahyudi et al., 2019). From a trade-off theory perspective, there is a positive debt-profitability relationship (Noubbigh, 2018; Serrasqueiro and Nunes, 2014), whereas, from the perspective of pecking-order theory, debt has a negative association. with profitability (Chen, Firth, and Rui, 2006). Meanwhile, there is no relationship between debt and profitability (Amanda, 2019; Harisa et al., 2019; Kebewar and Shah, 2012).

These inconsistent results could be due to differences in the samples used. Therefore, the current study separates low debt levels and high debt levels in examining the relationship between debt and profitability. Besides, this study focuses on SOEs and all sectors by controlling the industrial sector and SOEs. SOE banks' profitability is higher than the profitability of non-SOEs (Sutopo, Trinugroho, and Damayanti, 2017). Meanwhile, there is no difference between SOEs'SOEs' profitability and non-SOEs'non-SOEs' profitability when comparisons were made for all industrial sectors (Ardila, Saputra, Adiati, and Sutopo, 2018), and the differences or similarities between the two types of business entities can depend 
on the industry (Singh, 2019).

The theoretical framework underlying the debt-profitability relationship is as follows. SOEs as business companies aim to achieve high profits. To achieve this goal, SOEs can do, amongst other things, determine their capital structure. The use of higher debt will be beneficial for a company if it is followed by higher profitability. This increase in profitability requires attention to influencing factors such as profit before tax relative to total assets, interest rates, and tax rates. If these factors cannot be controlled, then a higher debt cannot achieve higher profitability.

The risk of profitability also needs to be considered because the more significant the fluctuation of profitability, the more likely it is that higher profits will not be achieved. Higher debt financing is not suitable for high profitability risks. From a trade-off theory perspective, increasing company value can be achieved by increasing debt financing. However, an increase in debt financing has a consequence of increased risk which can harm the company's value due to the potential costs of bankruptcy. Since profitability is an essential determinant of firm value, the debt-profitability relationship is similar to debt and firm value. This leads to the following predictions. The debt-profitability association depends on the level of debt. More specifically, there is a positive (negative) association between debt and profitability when the debt levels are relatively low (high).

\section{Methods}

The regression equations for testing the debt-profitability association are as follows.

$$
\text { EATTA }=\beta_{0}+\beta_{1} \text { TLTA }+\varepsilon
$$

EATTA $=\beta_{0}+\beta_{1} T L T A+\beta_{2} S I Z E++\beta_{n} \sum_{n=1}^{a}(T Y P E)+\beta_{n} \sum_{n=1}^{12}(S e c)$

$$
+\beta_{n} \sum_{n=2014}^{2018}(Y)+\varepsilon
$$

The measurement of the variables is presented in Table 1. Model (1) and Model (2) are applied for full sample and subsamples of low and high debt (TLTA) levels as follows.

- The full sample is used to test the debt-profitability association if there is no separation between low and high debt (TLTA) levels. The results are presented in Table 3.a.

- The subsamples of low and high TLTA levels - stage I are used to test the debtprofitability association for each subsample. Results are presented in Table 3.b. consisting of:

○ Low TLTA levels in Panel A 
○ High TLTA levels in Panel B.

- The subsamples of low and high TLTA levels - stage II are used to test the debtprofitability association for each group of low TLTA subsample and each group of high TLTA subsample. Results are presented in Table 3.c. which consist of:

Table 1. Variables Measurement

\begin{tabular}{|c|c|c|}
\hline Abbreviation & Variable & Measures \\
\hline TLTA & Debt financing or total assets funded through debt & $\begin{array}{l}\text { Total assets divided by total } \\
\text { liabilities (TL/TA) }\end{array}$ \\
\hline EATTA & $\begin{array}{l}\text { Profitability or the efficiency of an SOE in using } \\
\text { assets to generate profits after tax }\end{array}$ & $\begin{array}{l}\text { Earnings after tax divided by } \\
\text { total assets (EAT/TA) }\end{array}$ \\
\hline Size & Size of SOE & Natural log. of total assets \\
\hline TYPE & SOE type & \\
\hline Perum & $\begin{array}{l}\text { Perum (Type 1), which stands for "Perusahaan } \\
\text { Umum", is an SOE whose capital is not divided } \\
\text { into shares and is wholly owned by the State. }\end{array}$ & $\begin{array}{l}\text { It is given a value of } 1 \text { if an } \\
\text { SOE is a Persero } 1 \text { if an SOE is } \\
\text { a Perum, } 0 \text { if the other type }\end{array}$ \\
\hline Persero & $\begin{array}{l}\text { Persero (Type 2), which stands for "Perusahaan } \\
\text { Perseroan", is an SOE in the form of a limited } \\
\text { liability company whose capital is divided into } \\
\text { shares and at least } 51 \% \text { (fifty-one percent) of the } \\
\text { shares owned by the State. }\end{array}$ & $\begin{array}{l}\text { It is given a value of } 1 \text { if an } \\
\text { SOE is Persero, } 0 \text { if another } \\
\text { type }\end{array}$ \\
\hline PerseroTbk & $\begin{array}{l}\text { Persero Tbk (Type } 3 \text { ), or "Perusahaan Perseroan } \\
\text { Terbuka", is a Persero whose shares are traded on } \\
\text { the capital market. }\end{array}$ & $\begin{array}{l}\text { It is given a value of } 1 \text { if an } \\
\text { SOE is a Persero Tbk., } 0 \text { if } \\
\text { another type }\end{array}$ \\
\hline $\begin{array}{l}\text { SECTOR } \\
\text { (SEC) }\end{array}$ & Sector names (Sec1 - Sec 12) are listed below. & $\begin{array}{l}\text { Dummy variable, } 1 \text { if an SOE is } \\
\text { included in the relevant Sector } \\
\text { (for example Sector } 1 \text { ), } 0 \text { if it is } \\
\text { included in other sectors }\end{array}$ \\
\hline SEC1 & $\begin{array}{l}\text { Accommodation and Provision of Food and } \\
\text { Beverage }\end{array}$ & \\
\hline SEC2 & Processing industry & \\
\hline SEC3 & Information and Telecommunications & \\
\hline SEC4 & Financial Services and Insurance & \\
\hline SEC5 & Professional, Scientific, and Technical Services & \\
\hline SEC6 & Construction & \\
\hline SEC7 & Water Supply, Waste Management, and Recycling & \\
\hline SEC8 & Wholesale and retail & \\
\hline SEC9 & Mining and excavation & \\
\hline SEC10 & Agriculture, Forestry, and Fisheries & \\
\hline SEC11 & Real estate & \\
\hline SEC12 & Transportation and Warehousing & \\
\hline YEAR & $\begin{array}{l}\text { The years of observation include } 2014,2015 \\
2016,2017,2018 \text {. }\end{array}$ & $\begin{array}{l}\text { Dummy variable, } 1 \text { if an SOE is } \\
\text { included in the relevant } \\
\text { observation year (for example } \\
\text { in 2014), } 0 \text { if it is included in } \\
\text { another observation year }\end{array}$ \\
\hline
\end{tabular}


Note: Low TLTA - Small in Panel A, Low TLTA - Large in Panel A, High TLTA - Small in Panel B, High TLTA - Large in Panel B.

Source: Authors's definition and based on Law 19 of 2003 and from website of the Ministry of SOE.

List of State-Owned Enterprises (SOEs) and research variables sourced from the following website of the Ministry of State-Owned Enterprises (www.bumn.go.id). The research variables are calculated from tables containing a summary of the annual financial statements (balance sheet and income statement) from 2014-2018 available on the website.

The initial sample included 583 SOE observations. This number was reduced to 542 observations because of missing data. Then, the number of observations was reduced by 28 unaudited financial statements, resulting in a final sample of 514 SOE observations. The results of grouping observations into two subsamples based on debt financing level resulted in 170 SOEs included in relatively low debt financing and 344 SOEs with relatively high debt financing. According to the Indonesian Financial Services Authority, the determination of relatively low versus high debt financing uses one of the criteria that a stock can be included in the List of Sharia Securities. The criteria referred to are as follows "total debt based on interest compared to total assets is no more than $45 \%$ (forty-five percent)" except for total debt in this study is total liabilities regardless of interest-based debt or not due to data availability constraints about each of these types of debt. This study considers that TLTA that does not exceed $45 \%$ (forty-five percent) has a relatively low risk than those above 45 percent. Each subsample is divided into two groups: (1) a small TLTA group if TLTA is below or equal to the median and (2) a large TLTA group if TLTA is above the median. The number of observations of each group from the lowest group to the highest group was 85, 85, 172, and 172 observations, respectively.

\section{Results and Discussion}

Table 2 Panel B1.1. This shows that the mean value of debt financing (TLTA) of 0.18 is accompanied by a mean value of profitability (EATTA) of 0.09 . In Panel B.1.2. with a mean TLTA of 0.36, the mean EATTA drops to 0.07. In Panel B.2.1, with a higher mean TLTA of 0.59, the mean EATTA drops again to 0.03. Next, in Panel B.2.2. with a mean TLTA of 1,143 (the highest amongst the three groups), the mean EATTA was -0.02 , the lowest of the three groups. Mean TLTA 1.14 is more significant than one because equity is negative, so total liabilities are more significant than total assets. Thus, the descriptive statistics indicate a negative relationship between debt and profitability. 
Table 2. Descriptive Statistics

\begin{tabular}{|c|c|c|c|c|c|}
\hline Variable & Mean & Med & StDev & Min & Max. \\
\hline \multicolumn{6}{|c|}{ Panel A: Full Sample $(\mathrm{N}=514)$} \\
\hline EATTA & 0.03 & 0.03 & 0.09 & -0.65 & 0.29 \\
\hline TLTA & 0.67 & 0.59 & 0.71 & 0.06 & 9.15 \\
\hline TA* & 56.7 & 4.0 & 192.0 & 0.02 & 1335.0 \\
\hline SIZE & 15.18 & 15.19 & 2.36 & 9.90 & 21.01 \\
\hline \multicolumn{6}{|c|}{ Panel B1: Low TLTA $(\mathrm{N}=170)$} \\
\hline EATTA & 0.08 & 0.07 & 0.06 & -0.05 & 0.28 \\
\hline TLTA & 0.27 & 0.27 & 0.11 & 0.06 & 0.45 \\
\hline TA* & 35.0 & 3.2 & 170.6 & 0.1 & 1335.0 \\
\hline SIZE & 14.93 & 14.97 & 1.93 & 11.34 & 21.01 \\
\hline \multicolumn{6}{|c|}{ Panel B11: Low TLTA - Lower TLTA Group or $<=$ Median $(\mathrm{N}=85)$} \\
\hline EATTA & 0.09 & 0.08 & 0.06 & -0.01 & 0.28 \\
\hline TLTA & 0.18 & 0.18 & 0.06 & 0.06 & 0.27 \\
\hline TA* & 4.6 & 1.6 & 6.1 & 0.2 & 34.3 \\
\hline SIZE & 14.45 & 14.27 & 1.46 & 11.59 & 17.35 \\
\hline \multicolumn{6}{|c|}{ Panel B12: Low TLTA - Higher TLTA Group or $>$ Median $(\mathrm{N}=85)$} \\
\hline EATTA & 0.07 & 0.06 & 0.05 & -0.05 & 0.22 \\
\hline TLTA & 0.36 & 0.36 & 0.05 & 0.27 & 0.45 \\
\hline TA* & 65.2 & 4.4 & 238.0 & 0.1 & 1335.0 \\
\hline SIZE & 15.40 & 15.29 & 2.23 & 11.34 & 21.01 \\
\hline \multicolumn{6}{|c|}{ Panel B2: High TLTA $(\mathrm{N}=344)$} \\
\hline EATTA & 0.01 & 0.02 & 0.09 & -0.65 & 0.29 \\
\hline TLTA & 0.87 & 0.72 & 0.79 & 0.45 & 9.15 \\
\hline TA* & 67.5 & 4.5 & 201.2 & 0.02 & 1297.0 \\
\hline SIZE & 15.31 & 15.33 & 2.53 & 9.90 & 20.98 \\
\hline \multicolumn{6}{|c|}{ Panel B21: High TLTA - Lower TLTA Group or $<=$ Median $(\mathrm{N}=172)$} \\
\hline EATTA & 0.03 & 0.04 & 0.05 & -0.24 & 0.25 \\
\hline TLTA & 0.59 & 0.59 & 0.08 & 0.45 & 0.72 \\
\hline TA* & 33.3 & 5.3 & 99.2 & 0.03 & 693.8 \\
\hline SIZE & 15.36 & 15.48 & 2.19 & 10.39 & 20.36 \\
\hline \multicolumn{6}{|c|}{ Panel B22: High TLTA - Higher TLTA Group or > Median $(\mathrm{N}=172)$} \\
\hline EATTA & -0.02 & 0.01 & 0.12 & -0.65 & 0.29 \\
\hline TLTA & 1.14 & 0.85 & 1.04 & 0.72 & 9.15 \\
\hline TA* & 101.7 & 3.8 & 262.6 & 0.02 & 1296.9 \\
\hline SIZE & 15.26 & 15.14 & 2.83 & 9.90 & 20.98 \\
\hline
\end{tabular}

Source: Prepared by the authors' based on the results of analysis using statistical software.

Besides, the coefficient of variation (CV), the absolute value of the standard deviation divided by the mean, reflects that the risk of profitability is higher when debt financing is higher. In Panel B.1.1, the CV value of EATTA is 0.64. In Panel B.1.2, this CV value has increased to 0.73. Next, in Panel B.2.1, the CV of EATTA increased again to 1.44, and in Panel B.2.2, the CV of EATTA reached 5.95, which is the highest compared to the $\mathrm{CV}$ of the three groups.

The 2014-2018 period's annual data are presented in Figure 1 (Number of observations) and Figure 2 (Debt financing and profitability). The number of annual SOES observations from 2014-2018 has not changed significantly from year to 
year, and the number of SOEs in the low TLTA subsamples is less than that in the high TLTA subsamples (Figure 1). Besides, SOEs in the low TLTA subsample tend to achieve higher profitability than SOEs included in the high TLTA subsample (Figure 2). These results are consistent with the findings of Pontoh (2017). This pattern also did not change significantly from year to year. These results are similar to the TLTA-EATTA comparison results between groups of descriptive statistics in Table 2 as outlined above. Relatively low debt financing can achieve relatively high profitability and vice versa.

Figure 1. Number of Observation: 2014-2018

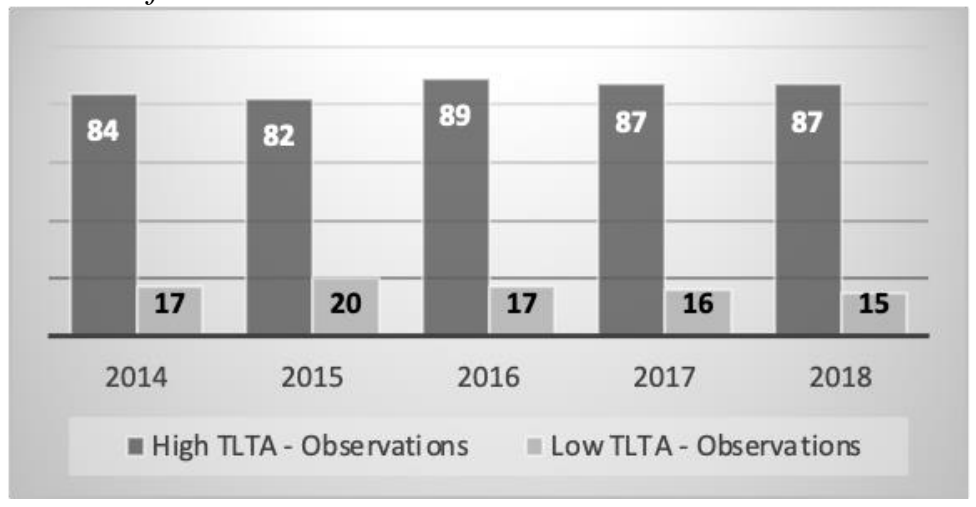

Source: Own creation.

Figure 2. Debt Financing (TLTA) and Profitability (EATTA): 2014-2018

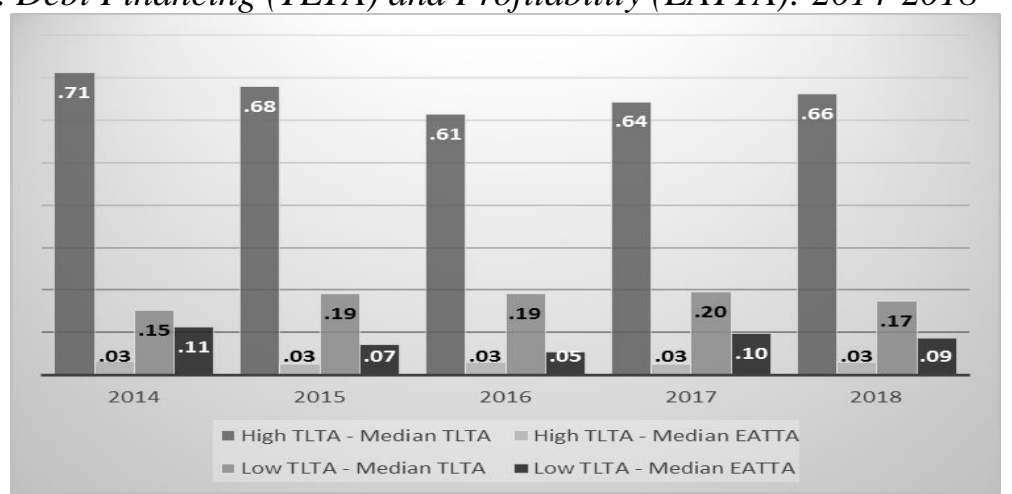

Source: Own creation.

The regression results of the debt-profitability relationship (TLTA-EATTA) are presented for the full sample $(\mathrm{N}=514)$ in Table 3.a. The results of Model (1) show that TLTA has a negative and significant coefficient (sig. $=0.000)$. In Model (2), with the addition of control variables, the TLTA coefficient is also harmful and remains significant $(\mathrm{sig} .=0.000)$. The addition of control variables in Model (2) increases the Adjusted R-Squared from 0.493 to 0.526 , which means that control variables help explain EATTA. These results indicate that SOEs with high debt 
financing tend to achieve low profitability. On the other hand, SOEs that have low debt financing tend to achieve high profitability.

Table 3.a Association between Debt Financing (TLTA) and Profitability (EATTA) - Full Sample $(N=514)$

\begin{tabular}{|l|c|c|c|c|}
\hline \multirow{2}{*}{ Variable } & Model 1 & & Model 2 & \\
\cline { 2 - 5 } & Coefficient & Sig. & Coefficient & Sig. \\
\hline (Constant) & .092 & .000 & .067 & .010 \\
\hline TLTA & -.090 & .000 &. .087 & .000 \\
\hline Size & & & -.001 & .681 \\
\hline Perum & & & .011 & .255 \\
\hline PerseroTbk & & & .004 & .641 \\
\hline Sector1 & & & -.030 & .302 \\
\hline Sector3 & & & .062 & .001 \\
\hline Sector4 & & & .029 & .003 \\
\hline Sector5 & & & .043 & .000 \\
\hline Sector6 & & & .055 & .070 \\
\hline Sector7 & & & .014 & .386 \\
\hline Sector8 & & & .023 & .169 \\
\hline Sector9 & & & .065 & .953 \\
\hline Sector10 & & & .001 & .003 \\
\hline Sector11 & & & .003 & .185 \\
\hline Sector12 & & & .019 & .031 \\
\hline Year2014 & & & 514 & .122 \\
\hline Year2015 & & .000 & 30.916 & .000 \\
\hline Year2017 & & & .543 & \\
\hline Year2018 & & & .526 & \\
\hline N & 514 & & & \\
\hline F & 500.462 & & & .0013 \\
\hline R Square & .494 & & & \\
\hline Adjusted R Square & .493 & & & \\
\hline
\end{tabular}

Source: Prepared by the authors' based on the results of analysis using statistical software.

Size as a control variable has an insignificant coefficient, meaning that it does not affect profitability. Likewise, the type of SOE does not affect profitability. This is indicated by the insignificant coefficients of Perum and PerseroTbk. In contrast to these results, the Industrial Sector helps explain profitability. Several sectors (SEC3, SEC4, SEC5, SEC7, SEC11, and SEC12) have positive and significant coefficients (sig.<0.01). These results mean that SOEs' profitability in these sectors is higher than that in Sector 2, which functions as a comparative sector (an excluded variable). SOEs in other sectors have profitability that is not significantly different from SOEs in Sector 2. The Y2017 coefficient is significantly positive (Sig. <0.05), indicating that profitability in 2017 is higher than profitability in 2016, which serves as a comparison (an excluded variable).

To test the impact of debt levels on debt financing associations with profitability, regression analysis was carried out for the subsamples of low and high debt levels. 
The low TLTA subsample results $(\mathrm{N}=170)$ and the high TLTA subsample $(\mathrm{N}=$ 344) are presented in Table 3b. The TLTA regression coefficient in Column Low TLTA Model (1) is negative and significant (Sig. <0.05). With the addition of control variables in Model (2), the TLTA coefficient remains negative but with a significance level of 10 percent. The explanatory power of the independent variable TLTA in Model (1) is low (Adjusted R-Squared $=0.020$ ). The addition of control variables in Model (2) helps explain the EATTA, which is shown by increasing the Adjusted R-Squared from 0.02 to 0.259 .

Table 3.b. Association between Debt Financing (TLTA) and Profitability (EATTA) for Low and High TLTA Levels

\begin{tabular}{|l|c|c|c|c|c|c|c|c|}
\hline \multirow{2}{*}{ Variable } & \multicolumn{3}{|c|}{ Low TLTA } & \multicolumn{4}{c|}{ High TLTA } \\
\cline { 2 - 9 } & \multicolumn{2}{|c|}{ Model 1 } & \multicolumn{2}{c|}{ Model 2 } & \multicolumn{2}{c|}{ Model 1 } & \multicolumn{2}{c|}{ Model 2 } \\
\cline { 2 - 9 } & Coef. & Sig. & Coef. & Sig. & Coef. & Sig. & Coef. & Sig. \\
\hline (Constant) & .105 & .000 & .248 & .000 & .079 & .000 & .005 & .897 \\
\hline TLTA & -.084 & .037 & -.076 & .074 & -.084 & .000 & -.079 & .000 \\
\hline Size & & & -.009 & .000 & & & .002 & .309 \\
\hline Perum & & & -.007 & .558 & & & .023 & .095 \\
\hline PerseroTbk & & & .001 & .970 & & & -.009 & .442 \\
\hline Sector1 & & & -.086 & .007 & & & .029 & .536 \\
\hline Sector3 & & & .105 & .000 & & & .036 & .192 \\
\hline Sector4 & & & .024 & .237 & & & .030 & .010 \\
\hline Sector5 & & & -.005 & .792 & & & .056 & .000 \\
\hline Sector6 & & & .033 & .125 & & & .031 & .015 \\
\hline Sector7 & & & -.045 & .047 & & & .050 & .110 \\
\hline Sector8 & & & -.017 & .347 & & & .016 & .508 \\
\hline Sector9 & & & -.052 & .024 & & & .033 & .230 \\
\hline Sector10 & & & -.015 & .337 & & & .003 & .859 \\
\hline Sector11 & & & .025 & .035 & & & .029 & .011 \\
\hline Sector12 & & & -.010 & .399 & & & .002 & .878 \\
\hline Year2014 & & & -.003 & .824 & & & .006 & .575 \\
\hline Year2015 & & & -.010 & .393 & & & .029 & .010 \\
\hline Year2017 & & & .009 & .687 & & & .024 & .029 \\
\hline Year2018 & & & .105 & .000 & & & .079 & .000 \\
\hline N & 170 & & 170 & & 344 & & 344 & \\
\hline F & 4.404 & .000 & 4.276 & .000 & 330.010 & .000 & 21.730 & .000 \\
\hline R Square & .026 & & .338 & & .491 & & .546 & \\
\hline Adjusted R Square & .020 & & .259 & & .490 & & .521 & \\
\hline
\end{tabular}

Source: Prepared by the authors' based on the results of analysis using statistical software.

The regression results in Table 3.b Column High TLTA subsample differ from those in Colum Low TLTA subsample. Column B shows that the TLTA coefficient for Model (1) is negative and significant (Sig. <0.01). The results of Model (2) show that the addition of control variables makes the TLTA coefficient consistently negative and significant (Sig.<0.01). The adjusted R-Squared of 0.490 for Model (1) increases to 0.521 for Model (2), indicating that the control variables help explain EATTA. 
Table 3.c. Association between Debt Financing (TLTA) and Profitability (EATTA) for Low TLTA Levels - Large vs Small and High TLTA Levels - Large vs Small

\begin{tabular}{|l|c|c|c|c|c|c|c|c|}
\hline \multirow{3}{*}{ Variable } & \multicolumn{3}{|c|}{ Low TLTA } & \multicolumn{4}{c|}{ High TLTA } \\
\cline { 2 - 9 } & \multicolumn{2}{|c|}{ Small } & \multicolumn{2}{c|}{ Large } & \multicolumn{2}{c|}{ Small } & \multicolumn{2}{c|}{ Large } \\
\cline { 2 - 9 } & Coef. & Sig. & Coef. & Sig. & Coef. & Sig. & Coef. & Sig. \\
\hline (Constant) & .318 & .000 & .275 & .000 & .045 & .323 & .060 & .358 \\
\hline TLTA & .257 & .025 & -.329 & .002 & -.146 & .003 & -.077 & .000 \\
\hline Size & -.018 & .000 & -.004 & .177 & .003 & .239 & -.002 & .610 \\
\hline Perum & .020 & .319 & -.018 & .309 & .002 & .842 & .065 & .050 \\
\hline PerseroTbk & .045 & .180 & -.010 & .712 & -.023 & .031 & .006 & .784 \\
\hline Sector1 & -.072 & .030 & .033 & .284 & .006 & .600 & .048 & .424 \\
\hline Sector3 & -.035 & .261 & -.019 & .588 & .063 & .000 & .060 & .006 \\
\hline Sector4 & -.040 & .091 & -.018 & .595 & .048 & .057 & .018 & .549 \\
\hline Sector5 & -.001 & .983 & -.011 & .582 & .011 & .593 & .070 & .430 \\
\hline Sector6 & .037 & .295 & -.013 & .717 & -.008 & .584 & .043 & .314 \\
\hline Sector7 & -.098 & .002 & -.006 & .838 & .024 & .021 & .012 & .626 \\
\hline Sector8 & -.013 & .566 & .013 & .388 & .021 & .076 & -.009 & .662 \\
\hline Sector9 & -.028 & .138 & -.014 & .341 & .024 & .024 & -.007 & .735 \\
\hline Sector10 & .025 & .140 & -.036 & .017 & .022 & .027 & .038 & .073 \\
\hline Sector11 & .000 & .982 & -.038 & .011 & .034 & .001 & .015 & .475 \\
\hline Sector12 & .026 & .129 & .111 & .000 & .031 & .237 & .005 & .924 \\
\hline Year2014 & .015 & .391 & -.030 & .321 & .013 & .705 & .021 & .568 \\
\hline Year2015 & .062 & .003 & .168 & .000 & .016 & .190 & .055 & .024 \\
\hline Year2017 & .167 & .130 & -.262 & .014 & .111 & .000 & .073 & .000 \\
\hline Year2018 & .275 & .000 & .045 & .323 & -.130 & .007 & -.081 & .000 \\
\hline N & 85 & & 85 & & 172 & & 172 & \\
\hline F & 4.055 & .000 & 3.909 & .000 & 3.639 & .000 & 12.350 & .000 \\
\hline R Square & .488 & & .479 & & .287 & & .577 & \\
\hline Adjusted R Square & .368 & & .357 & & .208 & & .530 & \\
\hline
\end{tabular}

Source: Prepared by the authors' based on the results of analysis using statistical software.

The regression results in Table 3.a and Table 3.b indicate that debt financing is not beneficial to SOEs; in this case, more significant debt financing does not impact greater profitability. Therefore, this study breaks down each of the low and high debt financing subsamples into two groups: the relatively small TLTA group (TLTA is smaller or equal to the median) and the relatively large TLTA group (TLTA is above the median). Regression results based on these groupings are presented in Table 3.c.

The results show that debt financing (TLTA) has a positive and significant coefficient (Sig. <0.05) for the low debt level subsample (Low TLTA) - a relatively small TLTA group. For the other groups, TLTA has a negative and significant coefficient (Sig. <0.01). These results mean that SOEs with more debt financing tend to achieve higher profitability when using lower levels of debt financing. On the other hand, SOEs with larger debt financing tend to experience lower profitability when these SOEs use high debt financing levels. More specifically, these results suggest that for SOEs with debt financing rates that do not exceed 27.4 percent, more significant debt financing can increase profitability. Conversely, 
when debt financing is more than 27.4 percent, larger debt financing results in lower profitability.

\section{Conclusions}

This study provides the following findings on the debt-profitability association of SOEs in Indonesia. First, the number of SOEs with low debt levels is smaller than the number of SOEs with high debt levels. The profitability (EATTA) for low debt levels is higher than that for high debt levels. These results were consistent over the observation period from 2014-2018.

Next, in general, debt financing has a negative association with profitability. However, the association between debt financing and profitability at a low level of debt financing is different from that at a high level. For low debt levels, there is a positive association between debt financing and profitability. Conversely, for high levels of debt, debt financing has a negative association with profitability. These results are consistent after controlling for the size, type, sector, and year of SOEs observation. This study's findings suggest the need to control SOE debt financing by keeping debt financing relatively low. More specifically, these findings have implications for SOEs in determining capital structure policies and SOEs' Ministry in establishing regulations related to debt financing in Indonesia. These findings suggest considering debt financing, which, in general, does not exceed 27 percent of total assets, so that an increase in debt is expected to contribute to an increase in SOEs' profitability. That way, SOEs are expected to fulfill their goal of achieving profits that will contribute to funding the state's administration for the welfare of the nation.

This study's limitations include that it does not provide empirical evidence about cases that deviate far from the average. For example, the case is that an SOE may have relatively large debt financing but achieve high profitability or vice versa. This is not the aim of this study. However, these findings provide a general overview of SOEs in Indonesia, especially in terms of the relationship between debt financing used and profitability achieved. Future studies can examine cases that deviate from this result, such as case studies or qualitative studies.

\section{References:}

Amanda, R.I. 2019. The Impact of Cash Turnover, Receivable Turnover, Inventory Turnover, Current Ratio and Debt to Equity Ratio on Profitability. Journal of Research in Management, 2(2), 14-22.

Ardila, L.N., Saputra, D.A., Adiati, A.K., Sutopo, B. 2018. Asset productivity, profitability, and firm value: Can state-owned companies outperform non-state-owned companies? International Journal of Business and Society, 19, 639-650.

Chen, G., Firth, M., Rui, O. 2006. Have China's enterprise reforms led to improved efficiency and profitability? Emerging Markets Review, 7(1), 82-109.

Collins, S.O., Clement, A.A., Funke, A.R. 2013. Profitability and Debt Capital Decision : A 
Reconsideration of the Pecking Order Model. International Journal of Business and Management, 8(13), 24-33.

Habib, H.J., Khan, F. 2016. Impact of Debt on Profitability of Firms: Evidence from NonFinancial Sector of Pakistan. City University Research Journal, 6(1), 70-80.

Hadiah, A.N. 2016. Financial Services Authority (OJK) Policy on Debt Proportion and Its Impact on the Profitability of DES Listed Companies in Indonesia. Shirkah: Journal of Economics and Business, 1(3), 327-337.

Harelimana, J.B. 2017. Effect of Debt Financing on Business Performance: A Comparative Study between I\&M Bank and Bank of Kigali, Rwanda. Global Journal of Management and Business Research: C Finance, 17(2), 37-45.

Harisa, E., Adam, M., Meutia, I. 2019. Effect of Quality of Good Corporate Governance Disclosure, Leverage and Firm Size on Profitability of Islamic Commercial Banks. International Journal of Economics and Financial Issues, 9(4), 189-196.

Holz, C.A. 2002. The impact of the liability - Asset ratio on profitability in China's industrial state-owned enterprises. China Economic Review, 13(1), 1-26.

Idris, M. 2019. Daftar 7 BUMN yang Tetap Rugi Meski Sudah Disuntik PMN (List of 7 SOEs that Remain Losing Even though they Have been Injected by State Equity Participation, PMN). Retrieved from: https://money.kompas.com/read/2019/12/21/142657926/daftar-7-bumn-yangtetap-rugi-meski-sudah-disuntik-pmn?page=all\#page2 .

Kartikasari, D., Merianti, M. 2016. The effect of leverage and firm size to profitability of public manufacturing companies in Indonesia. International Journal of Economics and Financial Issues, 6(2), 409-413.

Kebewar, M., Shah, S.M.N.A. 2012. The effect of debt on corporate profitability Evidence from French service sector. MPRA Paper No. 43304.

Lin, S., Rowe, W. 2006. Determinants of the profitability of China's regional SOEs. China Economic Review, 17(2), 120-141.

Nguyen, P., Crase, L. 2011. Vietnam's state-owned enterprise reform an empirical assessment in the international multimodal transport sector from the Williamson's TCE perspective. Asia Pacific Journal of Marketing and Logistics, 23(3), 411-422.

Nguyen, V.C., Nguyen, T.N.L., Tran, T.T.P., Nghiem, T.T. 2019. The impact of financial leverage on the profitability of real estate companies: A study from Vietnam stock exchange. Management Science Letters, 9(13), 2315-2326.

Obert, M., Olawale, F. 2010. Does debt really matter on the profitability of small firms? A perspective on small manufacturing firms. African Journal of Business Management, 4(9), 1709-1716.

Olufunso, F.O., Herbst, G., Roberts-Lombard, M. 2010. An investigation into the impact of the usage of debt on the profitability of small and medium enterprises in the Buffalo city municipality, South Africa. African Journal of Business Management, 4, 373-381.

Raisa, M.L., Cristian, M.M. 2015. Does Short Term Debt Affect Profitability? Evidence From The Romanian Listed Companies. Annals - Economy Series, 6, 228-233.

Shah, A., Ilyas, J. 2014. Is negative profitability-leverage relation the only support for the pecking order theory in case of Pakistani Firms? Pakistan Development Review, 53(1), 33-55.

Singh, O. 2019. State ownership and performance of firm: Evidence from India. Public Sector Economics, 43(2), 195-217.

Sutopo, B., Trinugroho, I., Damayanti, S.M. 2017. Politically connected banks: Some 
Indonesian evidence. International Journal of Business and Society, 18(1), 83-94.

UU.15. 2017. Undang-Undang Republik Indonesia Nomor 15 Tahun 2017 Tentang Anggaran Pendapatan Dan Belanja Negara Tahun Anggaran 2018 (Law of the Republic of Indonesia Number 15 of 2017 on the State Budget for the 2018 Budget Year).

UU.19. 2003. Undang-Undang Republik Indonesia Nomor 19 Tahun 2003 Tentang Badan Usaha Milik Negara (Law of the Republic of Indonesia Number 19 of 2003 on State-Owned Enterprises).

Wahyudi, R., Mujibatun, S., Riduwan, R. 2019. Debt and Equity-Based Financing, Size and Islamic Banks Profitability: Empirical Evidence from Indonesia. Iqtishadia, 12(2), 227-239.

Waluyo, W. 2018. Do efficiency of taxes, profitability and size of companies affect debt? A study of companies listed in the Indonesian stock exchange. European Research Studies Journal, 21(1), 331-339. 